\section{Influence of Plant Density on Yield and Fruit Quality of Greenhouse-grown Galia Muskmelons}

\author{
Juan C. Rodriguez ${ }^{1}$, Nicole L. Shaw ${ }^{2}$, and Daniel J. Cantliffe ${ }^{3,4}$
}

AdDitionAl INDEX wORDs. Cucumis melo, hydroponic, soilless media, protected agriculture, specialty melon

Summary. Galia-type muskmelon (Cucumis melo cv. Gal-152) was grown as a fall and spring crop to determine the effect of plant density $(1.7,2.5,3.3$, and 4.1 plants $/ \mathrm{m}^{2}$ ) on yield, fruit quality, plant growth, and economic feasibility for producing the crop in a greenhouse. Plant density had no influence on the early or total number of fruit produced per plant. Marketable yields increased linearly from 11.0 to $20.0 \mathrm{~kg} \cdot \mathrm{m}^{-2}$ in fall and from 21.9 to $48.3 \mathrm{~kg} \cdot \mathrm{m}^{-2}$ in spring with increasing plant density. Mean fruit size was unaffected by plant density during fall (mean weight, $1.0 \mathrm{~kg}$ ), but was reduced linearly during spring from $1.8 \mathrm{~kg}$ at 1.7 plants $/ \mathrm{m}^{2}$ to $1.5 \mathrm{~kg}$ at 4.1 plants $/ \mathrm{m}^{2}$. Soluble solids content was unaffected by plant density in either fall or spring and averaged $10.1 \%$ in both seasons. Number of leaves per plant was unaffected by plant density, but internode length was increased at 4.1 plants $/ \mathrm{m}^{2}$ compared with plants from the other densities. Increasing the plant density of 'Gal-152' muskmelon grown under protected cultivation led to increased yields in both fall and spring without negatively impacting fruit quality. When the market price is $\$ 1.44 / \mathrm{kg}$, increased yields at 3.3 plants $/ \mathrm{m}^{2}$ can potentially increase net returns over yields of plants spaced at 2.5 plants $/ \mathrm{m}^{2}$ by $25 \%$ and nearly double net returns from plants grown at 1.7 plants $/ \mathrm{m}^{2}$.

$\mathrm{P}$ roduction of crops in greenhouses is an intensive agriculture production system (Stanhill and Enoch, 1999) because more labor and materials are required than in open-field systems. Because investment and production costs are substantially higher in the greenhouse than in the field, methodologies used to produce greenhouse crops require more efficiency than those used in traditional field systems. Success of any greenhouse vegetable system relies on the production of greater fruit yields and better fruit quality. These higher yields are dependent on cultivar, crop management system, and growing season (Jensen and Malter, 1995; Lorenzo and Castilla, 1995). Because of the higher costs for materials and labor, careful consideration of optimum plant populations for soilless greenhouse

University of Florida, Institute of Food and Agricultural Sciences, Horticultural Sciences Department, Gainesville, FL 32611-0690

${ }^{1}$ Former graduate student.

${ }^{2}$ Senior biological scientist.

${ }^{3}$ Chair/professor.

${ }^{4}$ Corresponding author. E-mail: djcant@ufl.edu. crops is essential (Logendra et al., 2001).

Protected agricultural systems, such as passively ventilated greenhouses, could benefit vegetable growers in Florida (Cantliffe et al., 2001). Crops should be of high value and grown in efficient production systems to ensure that high returns are gained in relation to investment costs. New greenhouse crops such as Galia muskmelons could open new markets for future and existing greenhouse growers in Florida and other greenhouse production areas of the United States.

Muskmelons grown under greenhouse conditions at optimum plant populations and cultural practices can result in higher fruit production than field-grown crops (Waquant, 1974). Greater fruit yields may occur under greenhouse conditions than field systems because plants can be arranged more uniformly, avoiding large gaps between plants and rows while simultaneously optimizing light interception. Soilless culture and vertical plant growth (trellising) can improve available light interception, air movement, and microclimates of each plant, as well as promote the efficient use of water and nutrients through precise irrigation and recycling methods.

Because of the high investment costs, greenhouse production systems require selecting plant populations that make efficient use of all available space. Although spacing combinations between plants and between rows could result in high marketable yields per unit area, minimum space between rows is limited by the width of ladders and carts required for cultural practices such as pruning, training, pesticide application, and harvesting (Papadopoulos and Pararajasingham, 1997).

Under field conditions, muskmelon yields may be improved by increasing plant density (Maynard and Scott, 1998; Nerson, 2002). Although higher plant populations may result in increased marketable yield per unit area (Paris et al., 1985), the number of fruit per plant and fruit size are often reduced (Kultur et al., 2001). In field experiments conducted in north-central Florida, planting densities of 1.0, 2.0 , and 3.0 plants $/ \mathrm{m}^{2}$ of Galia-type muskmelons did not affect fruit yield (Paris et al., 1988). Soluble solids content (SSC) of muskmelon grown at higher densities has been reported

\begin{tabular}{llll}
\hline $\begin{array}{l}\text { Units } \\
\text { To convert U.S. to SI, } \\
\text { multiply by }\end{array}$ & U.S. unit & SI unit & $\begin{array}{l}\text { To convert SI to U.S., } \\
\text { multiply by }\end{array}$ \\
\hline 0.4047 & acre $(\mathrm{s})$ & $\mathrm{ha}$ & 2.4711 \\
0.3048 & $\mathrm{ft}$ & $\mathrm{m}$ & 3.2808 \\
0.0929 & $\mathrm{ft}^{2}$ & $\mathrm{~m}^{2}$ & 10.7639 \\
3.7854 & $\mathrm{gal}$ & $\mathrm{L}$ & 0.2642 \\
9.3540 & gal/acre & $\mathrm{L} \cdot \mathrm{ha}^{-1}$ & 0.1069 \\
2.5400 & inch $(\mathrm{es})$ & $\mathrm{cm}$ & 0.3937 \\
25.4000 & inch $(\mathrm{es})$ & $\mathrm{mm}$ & 0.0394 \\
0.4536 & lb & $\mathrm{kg}$ & 2.2046 \\
4.8824 & $\mathrm{lb} / \mathrm{ft}^{2}$ & $\mathrm{~kg} \cdot \mathrm{m}^{-2}$ & 0.2048 \\
1 & $\mathrm{ppm}$ & $\mathrm{mg} \cdot \mathrm{L}^{-1}$ & 1 \\
6.8948 & $\mathrm{psi}$ & $\mathrm{kPa}$ & 0.1450 \\
$\left({ }^{\circ} \mathrm{F}-32\right) \div 1.8$ & ${ }^{\circ} \mathrm{F}$ & ${ }^{\circ} \mathrm{C}$ & $\left(1.8 \times{ }^{\circ} \mathrm{C}\right)+32$ \\
& & &
\end{tabular}


to decrease as plant density increased from 2.0 to 8.0 plants $/ \mathrm{m}^{2}$ (Mendlinger, 1994), whereas others reported no difference in SSC from fruit grown at 3.6 and 7.3 plants $/ \mathrm{m}^{2}$ (Kultur et al., 2001).

Galia-type muskmelons planted in the field at plant densities of 1.0 and 2.0 plants $/ \mathrm{m}^{2}$ resulted in yields of 1.8 and 2.1 fruit $/ \mathrm{m}^{2}$ respectively (Paris et al., 1988). Total fruit weight at both plant densities was $\approx 2.3$ $\mathrm{kg} \cdot \mathrm{m}^{-2}$. Although more fruit per unit area were produced at the higher density, mean fruit weight per plant was less. Nerson et al. (1984) reported $20 \%$ greater yields of fieldproduced Galia muskmelon at 3.1 plants $/ \mathrm{m}^{2}$ than at 1.4 plants $/ \mathrm{m}^{2}$; however, mean fruit weights were similar. The European market desires a Galia fruit size around $1.0 \mathrm{~kg}$; therefore, higher densities may result in more desirable yields for certain markets (Ban et al., 2006). Galia muskmelon yields greater than $4.5 \mathrm{~kg} \cdot \mathrm{m}^{-2}$ were produced under field conditions in north-central Florida (Hochmuth et al., 1998). A muskmelon yield of $9.4 \mathrm{~kg} \cdot \mathrm{m}^{-2}$ was reported when plants were grown in walk-in tunnels using perlite soilless culture (Waldo et al., 1997).

Shaw et al. (2001) reported that Galia muskmelons grown in a passively ventilated greenhouse using perlite soilless culture can produce 9 to 15 fruit $/ \mathrm{m}^{2}$ at a plant density of 3.0 plants $/ \mathrm{m}^{2}$. Individual plant yields ranged from 3 to 5 fruit/plant with a mean fruit weight of $1.2 \mathrm{~kg} /$ fruit $\left(\approx 14.0 \mathrm{~kg} \cdot \mathrm{m}^{-2}\right)$. Consequently, yields were greater than those produced by plants grown in either walk-in tunnels (Waldo et al., 1997) or by field cultivation (Hochmuth et al., 1998).

Reports from countries where Galia melon is commercially produced indicate that yields of 4.3 to $5.9 \mathrm{~kg} \cdot \mathrm{m}^{-2}$ are generally achieved under protected structures (e.g., tunnels and greenhouses) using soil. These yields are common in Israel (Arava Desert) at a planting density of 1.3 plants $/ \mathrm{m}^{2}$ (Hecht, 1998; Z. Karchi, personal communication). Galia produced in Spain at a plant density of 2.0 plants $/ \mathrm{m}^{2}$ using coconut coir and rockwool as soilless media yielded $12.7 \mathrm{~kg} \cdot \mathrm{m}^{-2}$ (Torres and Miguel, 2003).

Production of Galia muskmelons in passively ventilated greenhouses in Florida using soilless culture may result in profitable yields when optimum plant densities are used. Selection of plant densities that efficiently use available growing space and labor may make it possible to obtain a greater yield and positive return on investment. The objective of this experiment was to evaluate the influence of plant density on fruit yield and quality, plant growth, and net return of Galia-type muskmelons grown in a passively ventilated greenhouse in Florida.

\section{Materials and methods}

Galia-type muskmelons were grown during Fall 2001 and Spring 2002 inside a single bay $\left(266 \mathrm{~m}^{2}\right)$ of a seven-bay, high-roof, passively ventilated greenhouse (Top Greenhouses Ltd., Barkan, Israel) located at the University of Florida's Horticultural Sciences Research Unit in Gainesville. The greenhouse was covered with double-layer polyethylene plastic (0.150 mm thickness; Ginegar Plastic Products Ltd., Kibbutz Ginegar, Israel). Sidewall curtains (3.6 m high) were closed to reduce heat loss during cold periods and were opened for ventilation during periods when temperatures reached $28{ }^{\circ} \mathrm{C}$. The sidewalls and roof vents were covered with an ultraviolet, 50-mesh insect screen (Meteor, Petah-Tikva, Israel) to prevent the entrance of insect pests and to retain beneficial insects and pollinators inside the greenhouse.

Seeds of 'Gal-152' (Hazera Seeds Ltd., Grover Beach, CA) were sown in polystyrene transplant flats (Speedling, Sun City, FL) filled with a 70 peatmoss : 30 vermiculite mix $(\mathrm{v}: \mathrm{v})$ (Terra-Lite Plug Mix; Terra Asgrow, Apopka, FL) on 15 July 2001 and on 31 Jan. 2002 for the fall and spring experiments respectively. When seedlings had two to three true leaves (10 Aug. 2001 and 17 Feb. 2002), they were transplanted into 1-m-long $x$ 0.10-m-wide resleeving polyethylene bags (Agrodynamics, East Brunswick, NJ) filled with $34 \mathrm{~L}$ horticultural grade perlite (Airlite Processing Corp. of Florida, Vero Beach, FL) placed within the production greenhouse. The various particle sizes of the horticultural grade (coarse) perlite ranged from 3.2 to $5.1 \mathrm{~mm}$ $(35.7 \%), 2.4$ to $3.2 \mathrm{~mm}(25.8 \%)$ and 1.3 to $2.4 \mathrm{~mm}(28.3 \%)$ (Cantliffe et al., 2003). Before transplanting, the bags were saturated with water. When at full capacity, each bag was allowed to drain through small horizontal slits cut $\approx 4 \mathrm{~cm}$ from the ground.

Weekly releases of adult lady beetles (Hippodamia convergens; IPM Laboratories, Locke, NY) at a rate of 10 to 20 beetles/plant and two releases of parasitic wasps (Eretmocerus californicus; IPM Laboratories) at a rate of 5 to 10 wasps/plant were not able to control a whitefly (Trialeurodes vaporariorum and Bemisia argentofolii) infestation near the end of the season in Fall 2001 after most fruit were already harvested. Preventive weekly releases of lady beetles and other beneficials, such as parasitic wasps (Aphidius colemani; IPM Laboratories), big-eye bugs (Geocoris punctipes; Entomos, LLC, Gainesville, FL), and minute-pirate bugs (Orius sp.; Entomos, LLC), maintained adequate control of common greenhouse pests in spring.

Two preventive applications of azoxystrobin (Quadris; Zeneca Agricultural Products, Wilmington, DE) fungicide were applied at 4 and 8 weeks after transplanting (rate, 0.42 $\mathrm{L} \cdot \mathrm{ha}^{-1}$ ) to control gummy stem blight (Didymella bryoniae).

Single rows of polyethylene bags (oriented North-South) were installed $1.2 \mathrm{~m}$ apart. Within-row spacing was varied to establish the four plant density treatments. Spacing between plants was either 50 , $33.3,25$, or $20 \mathrm{~cm}$; equivalent to plant densities of $1.7,2.5,3.3$, and 4.1 plants $/ \mathrm{m}^{2}$ respectively. Plant density treatments were arranged in a randomized complete-block design with four replications. Each plot consisted of nine bags (three rows with three bags in each row).

Plants were irrigated with a complete nutrient solution using two water-driven injectors (DI 16-11 GPM; Dosatron, Clearwater, FL) and supplied to each plant through a pressure-compensated emitter (flow rate, $0.5 \mathrm{gal} / \mathrm{h}$ at $25 \mathrm{psi}$; Netafim USA, Longwood, FL). The irrigation schedule throughout the season was programmed using a timer (Superior Controls Co., Valencia, CA), for which total volume was based on achieving plant need plus $20 \%$ to $30 \%$ daily leachate from the growing bags.

A complete nutrient solution was modified from previous greenhouse 
muskmelon trials (Shaw et al., 2001). At 0 to 2 weeks after transplanting (WAT), plants were fertigated with $120 \mathrm{mg} \cdot \mathrm{L}^{-1} \mathrm{~N}, 50 \mathrm{mg} \cdot \mathrm{L}^{-1} \mathrm{P}$, and 113 $\mathrm{mg} \cdot \mathrm{L}^{-1} \mathrm{~K}$ (Rodriguez et al., 2006). Although $\mathrm{N}$ and $\mathrm{K}$ concentrations were changed during the season, $\mathrm{P}$ concentration remained constant throughout the experiments. At flower initiation and fruit set (2-4 WAT), $\mathrm{N}$ and $\mathrm{K}$ were increased to $160 \mathrm{mg} \cdot \mathrm{L}^{-1} \mathrm{~N}$ and $135 \mathrm{mg} \cdot \mathrm{L}^{-1} \mathrm{~K}$. These concentrations were gradually increased at 4 WAT to $200 \mathrm{mg} \cdot \mathrm{L}^{-1} \mathrm{~N}$ and $165 \mathrm{mg} \cdot \mathrm{L}^{-1} \mathrm{~K}$. The plants received $200 \mathrm{mg} \cdot \mathrm{L}^{-1} \mathrm{~N}$ from fruit maturation to fruit color formation (4-8 WAT). When the first fruit had a light golden color, the nutritional concentrations were lowered to 170 $\mathrm{mg} \cdot \mathrm{L}^{-1} \mathrm{~N}$ and $135 \mathrm{mg} \cdot \mathrm{L}^{-1} \mathrm{~K}$, and were maintained at these levels until the end of the season (8-WAT). All other essential elements were retained at the same concentration from transplant to final harvest (Rodriguez et al., 2006).

Plants were individually trellised on rollerhook twines (Paskal Binding Accessories, Migdal Tefen, Israel) attached to a horizontal steel cable at $4 \mathrm{~m}$ above each plant row. All lateral branches below the ninth node were removed to facilitate reproductive growth, prevent excess vegetation, and reduce early fruit set that would limit early plant growth and subsequent fruit set. Lateral branches above the ninth node were pruned at the first node after the female flower was set and the fruit began to develop a dark green color and the appearance of a small sphere $(\geq 30 \mathrm{~mm}$ in diameter). Any lateral branches that did not set fruit were removed throughout the season. A class A hive of bumble bees (Bombus inpatiens; Natupol; Koppert Biological Systems, Ann Arbor, MI) was placed in the south section of the crop 4 WAT for pollination.

Fruit were harvested from 13 Oct. to 5 Dec. 2001 (fall), and from 23 Apr. until 5 July 2002 (spring). A total of 15 harvests were performed in fall and 25 harvests occurred in spring. The first four harvests were combined and designated as early yield. All fruit were harvested at fullslip (fruit had a golden yellow external color with minimal or no green background color, and complete abscission from the vine occurred by pressing on the peduncle). For each plot, number and weight of fruit per plant were recorded at every harvest. Using 2 fruit/plot, SSC was measured with a hand-held refractometer (AO 10430; Warner-Lambert Technologies, Keene, $\mathrm{NH}$ ).

Plant growth, expressed as total number of leaves and internode length, was also evaluated in Spring 2001 on two randomly selected plants from each plot. The total number of leaf nodes in each sample plant was counted, and length was measured from the base of the plant (at the cotyledons) to the top meristematic node. Internode length was calculated by dividing the total number of nodes by the stem length for each plant. Leaves per plant were also counted.

New York terminal market prices for Galia muskmelon were averaged from 1999 to 2003 to determine the value used in the economic budget. The average price during the 5-year period was $\$ 1.80 / \mathrm{kg}$; however, $\approx 20 \%$ is lost to transaction fees, and therefore the grower should receive about $\$ 1.44 / \mathrm{kg}$ in revenue. Total production costs were estimated from previous reported data where one 6-month crop of Galia muskmelon grown at 3.3 plants $/ \mathrm{m}^{2}$ using perlitefilled polyethylene bags resulted in total costs at $\$ 21.29 / \mathrm{m}^{2}$ or $\$ 6.45 /$ plant $/ \mathrm{m}^{2}$ (Shaw et al., 2004).

Data were subjected to an analysis of variance (SAS Institute, Cary, NC). Main effects of plant density were partitioned into orthogonal linear, quadratic, and cubic contrasts.

\section{Results and discussion}

Plant density did not significantly affect the number of fruit produced per plant or mean fruit weight for either the early or total yield in Fall 2001 (Table 1). Throughout the first four harvests (early harvest), $\approx 2$ fruit/plant were harvested with a mean fruit weight of $0.7 \mathrm{~kg}$. Regardless of plant density, nearly 5 fruit/ plant were harvested over 15 harvests, where the mean fruit weight was 1.2 $\mathrm{kg}$. Early and total yield per area increased linearly with increasing plant density; total marketable yield increased from $11.0 \mathrm{~kg} \cdot \mathrm{m}^{-2}$ at 1.7 plants $/ \mathrm{m}^{2}$ to $20 \mathrm{~kg} \cdot \mathrm{m}^{-2}$ at 4.1 plants $/ \mathrm{m}^{2}$. Several authors have previously reported increased muskmelon yields with increased plant density when field produced (Maynard and Scott, 1998; Mendlinger, 1994; Nerson, 2002). Fruit yield recorded during this fall season was nearly three times greater than that during a previous cultivar trial at the same location (Shaw et al., 2001), when 'Gal-152' produced $4.4 \mathrm{~kg} \cdot \mathrm{m}^{-2}$ when plant density was 1.9 plants $/ \mathrm{m}^{2}$. Fruit width, length, and SSC were unaffected by plant density at either the early or total harvests in fall. Yields may have been greater in the current experiment because it was conducted from August to December, unlike the study by Shaw et al. (2001), when plants were grown during the fallwinter months (October-February) when mean temperatures were cooler and day lengths were shorter. Mean SSC was $10.1 \%$, a value similar to that reported by Shaw et al. (2001) for the Galia-type muskmelon cultivar Gal-152.

In Spring 2002, plant density did not significantly affect early fruit production per plant, mean fruit weight, or fruit quality (Table 2). As in the fall, early yield per area increased linearly with increasing plant density. Total number of fruit per plant was unaffected by plant density and averaged 7.2 fruit/plant. Mean fruit weight decreased linearly, but yield per area increased linearly with increasing plant density. Increased plant densities in the field were reported to reduce mean fruit weight but overall to increase yield per area resulting from the increase in number of plants per area (Ban et al., 2006; Kultur et al., 2001; Nerson, 2002).

Shaw et al. (2001) recorded spring fruit yields of 'Gal-152' of $8.2 \mathrm{~kg} \cdot \mathrm{m}^{-2}$ when grown at a density of 1.9 plants $/ \mathrm{m}^{2}$. Total spring yields in this study were three times greater $\left(21.9 \mathrm{~kg} \cdot \mathrm{m}^{-2}\right)$ from plants grown at a similar plant density of 1.7 plants $/ \mathrm{m}^{2}$, and nearly six times greater $(48.3$ $\mathrm{kg} \cdot \mathrm{m}^{-2}$ ) from plants produced at 4.1 plants $/ \mathrm{m}^{2}$. Three to 5 fruit/plant are common yields in Israel, where Galia muskmelons were developed and are produced commercially (Nerson et al., 1984, 1989; Z. Karchi, pers. comm.). Highest yield of field-produced Galia melon in Israel occurred at plant densities of 20,000 plants $/$ ha (Nerson et al., 1989) and 31,250 plants/ha (Nerson et al., 1984), which are densities greater than that recommended for field-grown 
Table 1. Mean early and total fruit yields, fruit size, and fruit quality of 'Gal-152' muskmelon grown hydroponically at varying plant densities in Fall 2001.

\begin{tabular}{|c|c|c|c|c|c|c|}
\hline \multirow{2}{*}{$\begin{array}{l}\text { Density } \\
\left(\text { plants } / \mathrm{m}^{2}\right)^{\mathrm{z}}\end{array}$} & \multicolumn{3}{|c|}{ Yield } & \multicolumn{2}{|c|}{ Fruit size } & \multirow{2}{*}{$\begin{array}{l}\text { Fruit quality } \\
\text { SSC (\%) }\end{array}$} \\
\hline & Fruit no./plant & Fruit wt (kg/fruit $)^{\mathrm{z}}$ & Yield $\left(\mathrm{kg} \cdot \mathrm{m}^{-2}\right)^{\mathrm{z}}$ & $\overline{\text { Width }(\mathrm{mm})^{\mathrm{z}}}$ & Length $(\mathrm{mm})^{\mathrm{z}}$ & \\
\hline & \multicolumn{6}{|c|}{ Early yield ${ }^{y}$} \\
\hline 1.7 & 1.5 & 0.8 & 2.1 & 130 & 139 & 10.1 \\
\hline 2.5 & 1.4 & 0.7 & 2.7 & 131 & 137 & 9.9 \\
\hline 3.3 & 1.5 & 0.7 & 3.7 & 135 & 142 & 9.8 \\
\hline 4.1 & 1.4 & 0.6 & 3.2 & 130 & 138 & 10.2 \\
\hline Significance & NS & NS & $\mathrm{L}^{*}$ & NS & NS & NS \\
\hline \multicolumn{7}{|c|}{ Total yield ${ }^{y}$} \\
\hline 1.7 & 4.6 & 1.4 & 11.0 & 132 & 139 & 10.0 \\
\hline 2.5 & 4.7 & 1.3 & 15.3 & 132 & 140 & 10.2 \\
\hline 3.3 & 4.5 & 1.2 & 17.8 & 133 & 141 & 9.9 \\
\hline 4.1 & 4.8 & 1.0 & 20.0 & 130 & 138 & 10.4 \\
\hline Significance & NS & NS & $L^{*}$ & NS & NS & NS \\
\hline
\end{tabular}

${ }^{\mathrm{z}} \mathrm{l}$ plant $/ \mathrm{m}^{2}=0.0929 \mathrm{plant} / \mathrm{ft}^{2} ; \mathrm{l} \mathrm{kg}=2.2046 \mathrm{lb} ; \mathrm{l} \mathrm{kg} \cdot \mathrm{m}^{-2}=0.2048 \mathrm{lb} / \mathrm{ft}^{2} ; \mathrm{l} \mathrm{mm}=0.0394$ inch.

yearly yield is the total of the first four harvests. Total yield includes all 15 harvests, 13 Oct. to 5 Dec. 2001.

Ns, $*$ Nonsignificant or significant at $P<0.05$.

L, linear effect; SSC, soluble solids content.

muskmelon in Florida $[10,800$ plants/ha (Olson et al., 2006)], but similar to plant densities used in this study (17,000-41,000 plants/ha).

Fruit width, length, and SSC were not significantly affected by plant density at early harvest in spring. However, for the total harvest, fruit width and length decreased linearly with increasing plant density. Because plants had not yet grown to the top of the trellis, light interception may have been similar between the different plant densities during the early harvest. However, after the plants reached the top of the trellis, plants grown under higher plant densities would have greater light competition, potentially reducing fruit size.
Jovicich et al. (2004) reported a decrease in individual fruit size resulting from an increase in plant density for greenhouse-grown pepper (Capsicum annuum). Mean SSC was 10.3\% and similar to that reported by Shaw et al. (2001) during a different spring crop at the same location. Mendlinger (1994) reported Galia muskmelon SSC decreased with increasing plant density from 2 to 8 plants $/ \mathrm{m}^{2}$ when plants were grown using soil culture.

Plant internode length was influenced by plant density, but number of leaves per plant were unaffected (Table 3). The distance between internodes increased in plants grown at 4.1 plants $/ \mathrm{m}^{2}$ compared with the other plant densities. Papadopoulos and Pararajasingham (1997) reported that as plant density increased in a greenhouse tomato (Lycopersicon esculentum) crop, internode length also was increased-a result of plant competition for light. Increased plant density of greenhouse pepper also resulted in taller plants (Jovicich et al., 2004). Ban et al. (2006) reported the opposite affect in fieldgrown muskmelon that was not trellised: As plant spacing increased (density decreased), vine length increased. Nerson et al. (1984) reported greater number of leaves per unit area, higher leaf area index, and more dry matter accumulation of Galia muskmelon grown at 3.1 plants $/ \mathrm{m}^{2}$ than at 1.4 plants $/ \mathrm{m}^{2}$.

Table 2. Mean early and total fruit yields, fruit size, and fruit quality of 'Gal-152' muskmelon grown hydroponically at varying plant densities in Spring 2002.

\begin{tabular}{|c|c|c|c|c|c|c|}
\hline \multirow{2}{*}{$\begin{array}{l}\text { Density } \\
\left(\text { plants } / \mathrm{m}^{2}\right)^{\mathrm{z}}\end{array}$} & \multicolumn{3}{|c|}{ Yield } & \multicolumn{2}{|c|}{ Fruit size } & \multirow{2}{*}{$\begin{array}{c}\text { Fruit quality, } \\
\text { SSC (\%) }\end{array}$} \\
\hline & Fruit no./plant & Fruit wt (kg/fruit $)^{\mathrm{z}}$ & Yield $\left(\mathrm{kg} \cdot \mathrm{m}^{-2}\right)^{\mathrm{z}}$ & $\overline{\text { Width }(\mathrm{mm})^{\mathrm{z}}}$ & Length $(\mathrm{mm})^{\mathrm{z}}$ & \\
\hline & \multicolumn{6}{|c|}{ Early yield ${ }^{y}$} \\
\hline 2.5 & 2.0 & 1.8 & 8.9 & 137 & 144 & 10.1 \\
\hline 3.3 & 1.9 & 1.8 & 11.0 & 136 & 145 & 9.5 \\
\hline 4.1 & 1.9 & 1.7 & 12.3 & 134 & 141 & 10.2 \\
\hline 1.7 & 7.1 & 1.8 & 21.9 & 138 & 146 & 10.4 \\
\hline 2.5 & 7.3 & 1.7 & 31.7 & 137 & 144 & 10.5 \\
\hline 3.3 & 7.2 & 1.7 & 40.5 & 136 & 144 & 10.3 \\
\hline 4.1 & 7.2 & 1.5 & 44.3 & 132 & 139 & 10.1 \\
\hline Significance & NS & $\mathrm{L}^{*}$ & $\mathrm{~L}^{*}$ & $\mathrm{~L}^{*}$ & $\mathrm{~L}^{*}$ & NS \\
\hline
\end{tabular}

${ }^{\mathrm{z}} \mathrm{l}$ plant $/ \mathrm{m}^{2}=0.0929$ plant $/ \mathrm{ft}^{2} ; \mathrm{l} \mathrm{kg}=2.2046 \mathrm{lb} ; \mathrm{l} \mathrm{kg} \cdot \mathrm{m}^{-2}=0.2048 \mathrm{lb} / \mathrm{ft}^{2} ; \mathrm{l} \mathrm{mm}=0.0394$ inch.

${ }^{y}$ Early yield is the total of the first four harvests. Total yield includes all 25 harvests, 23 Apr. to 5 July 2002 .

Ns, * Nonsignificant or significant at $P<0.05$.

$\mathrm{L}$, linear effect, SSC, soluble solids content. 
Table 3. Mean internode length and leaf number per plant of 'Gal-152' muskmelon grown hydroponically at varying plant densities in Spring 2002.

\begin{tabular}{lcc}
\hline $\begin{array}{l}\text { Density } \\
\left(\text { plants } / \mathbf{m}^{2}\right)^{\mathbf{z}}\end{array}$ & $\begin{array}{c}\text { Internode } \\
\text { length }(\mathbf{m m})^{\mathbf{z}}\end{array}$ & Leaf no./plant \\
\hline 1.7 & 50.2 & 44 \\
2.5 & 50.7 & 44 \\
3.3 & 50.5 & 43 \\
4.1 & 56.8 & 42 \\
Significance & $*$ & NS \\
\hline
\end{tabular}

${ }^{2} 1$ plant $/ \mathrm{m}^{2}=0.0929$ plant $/ \mathrm{ft}^{2} ; 1 \mathrm{~mm}=0.0394$ inch.

Ns, $*$ Nonsignificant or significant at $P<0.05$.

Table 4. Economic returns of a 6-month crop of 'Gal-152' muskmelon grown hydroponically at varying plant densities in Spring 2002.

\begin{tabular}{lcccc}
\hline $\begin{array}{l}\text { Density } \\
\left(\text { plants } / \mathbf{m}^{2}\right)^{\mathbf{z}}\end{array}$ & $\begin{array}{c}\text { Yield } \\
\left(\mathbf{k g} \cdot \mathbf{m}^{-\mathbf{2}}\right)^{\mathbf{z}}\end{array}$ & $\begin{array}{c}\text { Gross returns } \\
\left(\$ / \mathbf{m}^{2}\right)^{\mathbf{y}}\end{array}$ & $\begin{array}{c}\text { Cost of production } \\
\left(\$ / \mathbf{m}^{2}\right)^{\mathbf{x}}\end{array}$ & $\begin{array}{c}\text { Net returns } \\
\left(\$ / \mathbf{m}^{2}\right)^{\mathbf{w}}\end{array}$ \\
\hline 1.7 & 21.9 & 31.54 & 10.97 & 20.57 \\
2.5 & 31.7 & 45.65 & 16.13 & 29.52 \\
3.3 & 40.5 & 58.32 & 21.29 & 37.03 \\
4.1 & 44.3 & 63.79 & 26.45 & 37.34 \\
\hline
\end{tabular}

${ }^{\mathrm{z}} 1$ plant $/ \mathrm{m}^{2}=0.0929$ plant $/ \mathrm{ft}^{2} ;$ yield $=$ mean marketable fruit weight of all 25 harvests $(23$ Apr. to 5 July 2002$), 1$ $\mathrm{kg} \cdot \mathrm{m}^{-2}=0.2048 \mathrm{lb} / \mathrm{ft}^{2}$.

${ }^{y}$ Gross returns $=$ yield $\times$ market price $(\$ 1.44 / \mathrm{kg}), \$ 1.00 / \mathrm{kg}=\$ 0.4536 / \mathrm{lb}$.

${ }^{x}$ Cost of production is estimated from Shaw et al. (2004), where total production cost reported for one 6-month crop of Galia muskmelon produced in a passively ventilated greenhouse using perlite-filled polyethylene bags was $\$ 21.29 / \mathrm{m}^{2}$ at 3.3 plants $/ \mathrm{m}^{2} ; \$ 1.00 / \mathrm{m}^{2}=\$ 0.0929 / \mathrm{ft}^{2}$

wet returns $=$ gross returns minus cost of production.

Because the majority of muskmelon fruit are sold on a per-fruit basis, the increased number of fruit produced per hectare as a result of increased plant density is economically important. No information exists on plant spacing of Galia muskmelon in a high-roof, passively ventilated greenhouse. The highest density tested within the current study is four times greater than the recommended plant density for field-produced muskmelon in Florida $[10,800$ plants/ha (Olson et al., 2006) ]. However, Shaw et al. (2001) reported that Galia production in the field is discouraged in Florida because of problems attributed to rain and insect pests, which can be alleviated under greenhouse conditions.

An enterprise budget for greenhouse Galia muskmelon production has been previously reported (Shaw et al., 2004). Based on the results of Shaw et al. (2004), where cost of production was $\$ 21.29 / \mathrm{m}^{2}$ at 3.3 plants $/ \mathrm{m}^{2}$, cost of production of the current research increased from $\$ 10.97 / \mathrm{m}^{2}$ at 1.7 plants $/ \mathrm{m}^{2}$ to $\$ 26.45 / \mathrm{m}^{2}$ at 4.1 plants $/ \mathrm{m}^{2}$ (Table $4)$. The potential net return for a single 6-month spring crop of 'Gal152 ' produced under protected cultivation is about $\$ 370,000 /$ ha at 3.3 or
4.1 plants $/ \mathrm{m}^{2}$. Because the increased production costs of 'Gal-152' grown at 4.1 plants $/ \mathrm{m}^{2}$ reduced net profits similar to those achieved at 3.3 plants $/ \mathrm{m}^{2}$, growers in Florida are recommended to produce greenhouse Galia muskmelon at 3.3 plants $/ \mathrm{m}^{2}$. Producing a fall crop may be profitable because many variable costs associated with a single crop, such as containers, media, fertilizer, and irrigation water, can be reused or recycled during the fall. Furthermore, fixed costs would then be spread over an entire 12 months (data not shown). The Galia melon was developed under desert field conditions in Israel, but in recent years, much of the production in Israel and other Mediterranean countries has been converted to protected cultivation. Regardless, Galia melon has always been marketed as a high-quality fruit. In Florida, intensive protected cultivation will ensure production of high-quality fruit that can be sold for premium prices.

\section{Literature cited}

Ban, D., S. Goreta, and J. Borosic. 2006. Plant spacing and cultivar affect melon growth and yield components. Sci. Hort. 109:238-243.
Cantliffe, D.J., J. Funes, E. Jovicich, A. Paranjpe, J. Rodriguez, and N. Shaw. 2003. Media and containers for greenhouse soilless grown cucumbers, melons, peppers, and strawberries. Acta Hort. 614:199-203.

Cantliffe, D.J., N. Shaw, E. Jovicich, J.C. Rodriguez, I. Secker, and Z. Karchi. 2001. Passive ventilated high-roof greenhouse production of vegetables in a humid, mild winter climate. Acta Hort. 559:195-201.

Hecht, D. 1998. Melon cultivation. State of Israel, Ministry of Agr. and Rural Development, Bet Dagan.

Hochmuth, R.C., L.L. Davis, and G.J. Hochmuth. 1998. Evaluation of standard and specialty melon cultivars for north Florida. Fla. Coop. Ext. Serv., Univ. of Fla, Gainesville, FL.

Jensen, M.H. and A.J. Malter. 1995. Protected agriculture: A global review. World Bank technical paper, no. 253. The World Bank, Washington, DC.

Jovicich, E., D.J. Cantliffe, and P.J. Stoffella. 2004. Fruit yield and quality of greenhouse-grown bell pepper as influenced by density, container, and trellis system. HortTechnology 14:507513.

Kultur, F., H.C. Harrison, and J.E. Staub. 2001. Spacing and genotype affect fruit sugar concentration, yield, and fruit size of muskmelon. HortScience $36: 274-278$.

Logendra, L.S., T.J. Gianfagna, D.R. Specca, and H.W. Janes. 2001. Greenhouse tomato limited cluster production systems: Crop management practices affect yield. HortScience 36:893-896.

Lorenzo, P. and N. Castilla. 1995. Bell pepper yield response to plant density and radiation in unheated plastic greenhouse. Acta Hort. 412:330-335.

Maynard, E.T. and W.D. Scott. 1998. Plant spacing affects yield of 'Superstar' muskmelon. HortScience 33:52-54.

Mendlinger, S. 1994. Effect of increasing plant density and salinity on yield and fruit quality in muskmelon. Sci. Hort. 57:41-49.

Nerson, H. 2002. Relationship between plant density and fruit and seed production in muskmelon. J. Amer. Soc. Hort. Sci. 127:855-859.

Nerson, H., M. Edelstein, H.S. Paris, Y. Burger, and B. Doran. 1989. Effects of spacing and irrigation management on yield, concentration, and quality of 'Qalya' and 'Galia' muskmelons. Hassadeh 69:1624-1629 (in Hebrew with English abstract). 
Nerson, H., M. Edelstein, H.S. Paris, Z. Karchi, and A. Govers. 1984. Effects of population density and plant spacing on the vegetative growth, flowering and yield of cv. Galia muskmelon. Hassadeh 64:698-702 (in Hebrew with English abstract).

Olson, S.M., E.H. Simonne, W.M. Stall, P.D. Roberts, S.E. Webb, T.G. Taylor, and S.A. Smith. 2006. Cucurbit production in Florida, p. 191-237. In: S.M. Olson and E. Simonne (eds.). Vegetable production handbook for Florida 2006-2007. Univ. of Fla./Inst. of Food and Agr. Sci. Coop. Ext Serv., Gainesville, FL.

Papadopoulos, A.P. and S. Pararajasingham. 1997. The influence of plant spacing on light interception and use in greenhouse tomato (Lycopersicum esculentum Mill.): A review. Sci. Hort. 69:1-29.
Paris, H.S., T.G. McCollum, H. Nerson, D.J. Cantliffe, and Z. Karchi. 1985. Breeding of concentrated-yield muskmelons. J. Hort. Sci. 60:335-339.

Paris, H.S., H. Nerson, Y. Burger, M Edelstein, Z. Karchi, T. McCollum, and D.J. Cantliffe. 1988. Synchrony of yield of melons as affected by plant type and density. J. Hort. Sci. 63:141-147.

Rodriguez, J.C., D.J. Cantliffe, N.L. Shaw, and Z. Karchi. 2006. Soilless media and containers for greenhouse production of 'Galia' type muskmelon. HortScience 41:1200-1205.

Shaw, N.L., D.J. Cantliffe, J. Rodriguez, and C. Shine. III 2004. Economic feasibility of producing Galia muskmelons in passive-ventilated greenhouses and soilless culture in north-central Florida. Proc. Fla. State Hort. Soc. 117:38-42.
Shaw, N.L., D.J. Cantliffe, and B.S. Taylor. 2001 . Hydroponically produced Galia muskmelon: What's the secret? Proc. Fla. State Hort. Soc. 114:288293.

Stanhill, G., and H.Z. Enoch (eds.). 1999. Greenhouse ecosystems. Elsevier, New York.

Torres, J.M. and M.J. Miguel. 2003. La geografía del comercio del melón. Hort. Intern. 40:16-25 (in Spanish).

Waldo, E.A., G.J. Hochmuth, and D.J. Cantliffe. 1997. Protected culture of 'Galia' melons. Proc. Fla. State Hort. Soc. 110:303-306.

Waquant, C. 1974. Influence of climatic conditions on muskmelon production. Acta Hort. 42:241-254. 